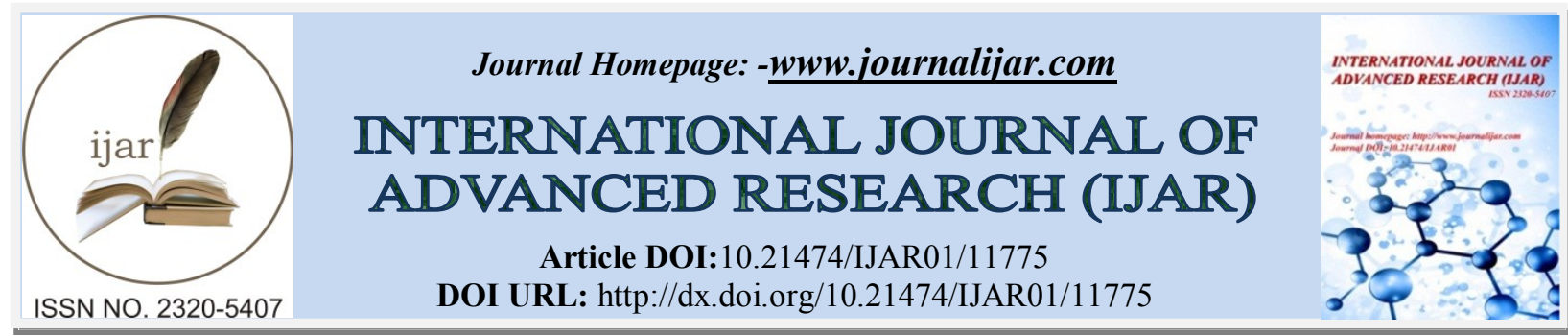

RESEARCH ARTICLE

\title{
EVALUATION OF SOIL CONTAMINATION BY METALLIC TRACE ELEMENTS TO THE ROADSIDE
} ON THE LUBUMBASHI-KIPUSHI SECTION (DRC)

\begin{abstract}
Muhune Kitule Simon ${ }^{1}$, Mbayo Kitambala Marsi ${ }^{1}$, Tshisand Tshibwid Patrick ${ }^{1}$, Muyumba Nonga Welcome $^{2,4}$, Kayembe Kazadi Oscar ${ }^{1}$, Kaya Muyumba Donato ${ }^{1}$, Banza Ilunga Bienvennue ${ }^{1}$, Misenga Twite Antoinette $^{3}$, Lukusa Tresor ${ }^{1,5}$, Tshibanda Kabumana Dieudonne ${ }^{1}$, Kalonda Mutombo Emery ${ }^{1}$ and Lumbu Simbi Jean-Baptiste ${ }^{1}$

1. Department of Chemistry, Faculty of Sciences, University of Lubumbashi, Lubumbashi, DR Congo.

2. Department of Chemistry, Teacher's Training College of Lubumbashi, Lubumbashi, DR Congo.

3. Department of Chemical Engineering and Bioengineering, Washington State University, Washington, USA.

4. Unit of Therapeutic Chemistry and Pharmacognosy, Mons (UMONS), Bât 6, Chemin du Champ de Mars 25, 7000 Mons, Belgium.

5. Department of Chemical Engineering, Vaal University of Technology, Republic of South Africa.
\end{abstract}

\section{Manuscript Info}

Manuscript History

Received: 25 July 2020

Final Accepted: 28 August 2020

Published: September 2020

Key words:-

Contamination, Soil, ETM, Distribution, Road, And Chemical Pollution

\section{Abstract}

The Contamination of soils near the road Lubumbashi-Kipushi was investigated. Analysis of cadmium, copper, lead, and zinc contents, as well as pH-water samples, yielded average MTEs with a decreasing profile concerningthe distance from the road with $\mathrm{pH}$ values around 7.5. At the surface, copper gave the highest value $(14459 \mathrm{mg} / \mathrm{kg})$ of all MTE studied near the road at $0.5 \mathrm{~m}$ and the lowest value $(2271 \mathrm{mg} / \mathrm{kg})$ at $20 \mathrm{~m}$ of the road. Cadmium did not vary statistically but gave the lowest value $(54.5 \mathrm{mg} / \mathrm{kg})$ of all MTE at $20 \mathrm{~m}$ from the road with a high value of $478 \mathrm{mg} / \mathrm{kg}$ at $2.5 \mathrm{~m}$ from the road. Compared to sampling sites, statistical averages for these three variables $(\mathrm{Cu}, \mathrm{Pb}$, and $\mathrm{Zn})$ showed a change in copper content with a high value of $13675 \mathrm{mg} / \mathrm{kg}$ at site 4 and a low value of $4771 \mathrm{mg} / \mathrm{kg}$ at site 3. Cadmium did not give a significant variation from sites. In-depth, the elements displayed the same behavior as on the surface. This was the case of copper, which had an average concentration of $14751 \mathrm{mg} / \mathrm{kg}$ at a distance of $0.5 \mathrm{~m}$ close to the road and its smallest value was $2151 \mathrm{mg} / \mathrm{kg}$ at $50 \mathrm{~m}$. The $\mathrm{pH}$ did not show any significant variations. The correlation between the parameters studied showed that $\mathrm{Cu}, \mathrm{Cd}$, and $\mathrm{Pb}$ contents were bound, but they were independent of $\mathrm{pH}$ while $\mathrm{Zn}$ was bound to $\mathrm{pH}$.

Copy Right, IJAR, 2020. All rights reserved.

\section{Introduction:-}

Soil contamination is a major concern for emerging countries. The presence of metallic trace elements (MTE) from mining activities, such as lead $(\mathrm{Pb})$, cadmium $(\mathrm{Cd})$, copper $(\mathrm{Cu})$, zinc $(\mathrm{Zn})$, and mercury $(\mathrm{Hg})$ in the environment should be well controlled because these metals are often found in non-biodegradable and toxic states. Thus, they can persist in the environment for long periods (Nhari et al., 2014).

Corresponding Author:- Muhune Kitule Simon

Address:- Department of Chemistry, Faculty of Sciences, University of Lubumbashi, 2 av. de la Maternité, Commune of Lubumbashi, DR Congo. 
Contamination of an environment by MTEs according to Baize (1997) refers to an increase in the total concentrations of these MTEs in the environment following by significant anthropogenic inputs. According to Akujobi (2012),MTEs are important environmental pollutants, especially in environments with high concentrations of anthropogenic activity. Their presence in the atmosphere, soil, and water, even in the form of traces, can cause serious problems for all organisms. The accumulation of heavy metals in soils is a concern in agricultural production because of their adverse effects on crop growth, food quality, and the environment (Augusto, 2001).

Near roads, soils, plants, and animal organisms living in this area are subject to contamination of the metallic elements emitted by mining activities and fumes released by vehicles fumes (Ghrefat and Yusuf, 2006). According to Lee et al. (2001), mining is one of the most important sources of heavy metals in the environment. Extraction and mining operations, ore concentration, metal production, and waste disposal are major sources of environmental contamination (Adriano, 1986). As a result, high levels of heavy metal concentrations can be found near mines due to landfill and dispersal of mining waste in surrounding soils, crops, and streams.

Mining and processing of minerals in DR Congo are the basis of soil contamination (Muyumba et al 2015). Since 1911, the Mining Union of Upper Katanga (UMHK), which became Gecamines in 1966, operates mines in the province and processes extracted minerals. Lubumbashi and Kipushi form a copper arc of Upper Katanga. Therefore, a copper refinery was established in the city of Lubumbashi in the early twentieth century (Isabelle, 2010). The ore extracted at Kipushi was regularly transported to Lubumbashi for processing. Implementation of mining operations in the province of Katanga is more likely resulting in soil contamination. Consequently, there is the dense road traffic (transport of minerals) andthe risk of contamination of soils near roads by projections due to shaking and accidental fallouts.

MTEs are continuously added to the soil through various activities. There are numerous emission sources of MTEs, notably industry, transport, agricultural practices, urban sludge and compost, and alteration of parent rocks. Traffic and road infrastructures are also sources of MTE, but their pollution is only a fraction of the chronic pollution from vehicles in use and tear of the road equipment (Setra, 2004).

More than a decade ago, Ward (1997), Pagotto (1999), and Dalmas (2000) were able to denounce soil contamination in the road sector in France. Muyumba et al. (2020) also made this finding in their work on the Lubumbashi-Likasi road. For this reason, we felt that it was necessary to evaluate the soil contamination on the Lubumbashi-Kipushi road because of the road traffic on this specific road.

The objective of this work is to evaluate the distribution of MTEs (cadmium, copper, lead, and zinc) along the Lubumbashi-Kipushi road.

\section{Material and Methods:-}

\section{Description of the Study Site:}

The Lubumbashi-Kipushi road has located in the northwest of the city of Lubumbashi.It joins the Kasumbalesa road in the Upper Katanga province in the Democratic Republic of Congo. The city of Kipushi is located about $30 \mathrm{~km}$ from the city of Lubumbashi. Kipushi is a mining town where some mining companies are located, such as Gecamines, CMSK, KOTA mining, KICO mining, etc. The ore mine in the town of Kipushi contains germanium, gallium, copper, lead, zinc, cobalt, cadmium, silver, etc. (Kitobo, 2009; Muyumba et al., 2016). Below is a map showing the geographical location of our study area. 


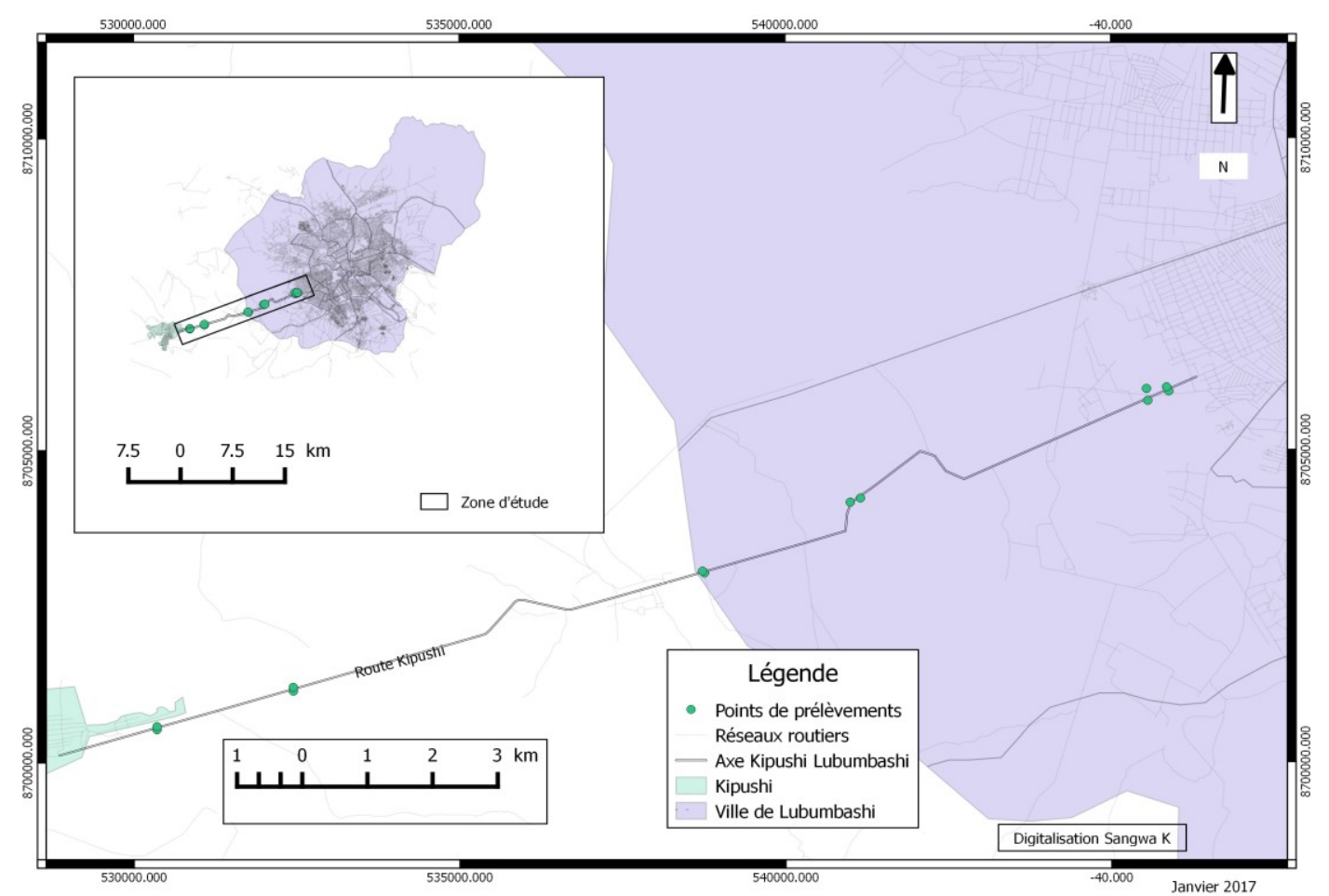

Figure 1:- Sampling Mapping.

\section{Sampling and Chemical Analysis:}

Different sampling sites about the environmental situation were located. The first site (S1) is located before the main entrance of the Mining Company of Katanga (SOMIKA), the second site (S2) is situated just after the same copper mining plant. The third site (S3) is found at Kilimasimba. The fourth site (S4) is located after the Mimbulu farm (Fermil). The fifth site (S5) is located at the Kafubu River near Kota Mining. Finally, the last site (S6) is located at the Welcome Panel of the city of Kipushi. This road is one of the axes used by mining operators since colonial times, this is why it was chosen for this study.

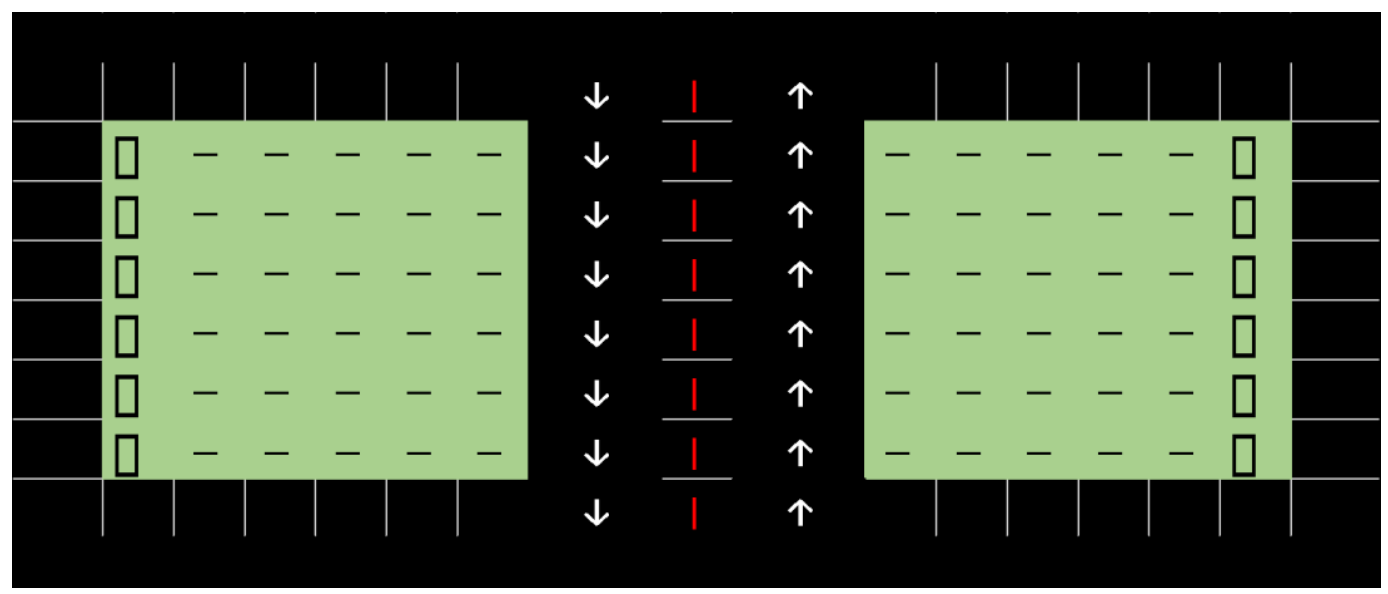

Figure 2:- Sampling Scheme.

Six points on the left and six points on the right were taken at different distances away from the road $(\mathrm{A}=0.5 \mathrm{~m}, \mathrm{~B}$ $=2.5 \mathrm{~m}, \mathrm{C}=5 \mathrm{~m}, \mathrm{E}=10 \mathrm{~m}, \mathrm{~F}=20 \mathrm{~m}$, and $\mathrm{G}=50 \mathrm{~m}$ ). At each sampling point, two samples at two depths, at $2 \mathrm{~cm}$ and at $10 \mathrm{~cm}(0$ to $2 \mathrm{~cm}$ and from 2 to $10 \mathrm{~cm})$, were taken. Twelve samples were taken on the left and the other twelve on the right side of each site. At each site, we sampled 24 samples and 144 samples from all 6 sites. The figure above presents an overview of our sampling. 
Study materials consist of the ground taken along the Kipushi road. The packaging of our equipment was carried out in the polyethylene transparent. Each sample was kept in the laboratory at room temperature.The drying mode consisted of spreading our samples in the open air. After drying, each sample was sieved at 2 mm size to obtain a size adapted to two millimeters.

\section{Data Analysis:}

The results obtained in this study are displayed as mean \pm SEM. Data analysis was done using one-way ANOVA. Values were considered significant at $P<0.05$.

The principal component analysis (PCA) was used to explain associations of the observations having close characteristics.

\section{Results:-}

Distribution of MTEs in Surface Soils (0-2 cm) of the Kipushi-Lubumbashi Road Axis:

The ANOVA allowed to characterize the distribution of MTE and $\mathrm{pH}$ in the surface layer of soils around the Lubumbashi-Kipushi road (Table 1).

Table 1:- Mean Concentrations (mg/kg) of MTE and $\mathrm{pH}$ in SurfaceSoils (0 to $2 \mathrm{~cm})$.

\begin{tabular}{|c|c|c|c|c|c|c|}
\hline Factors & & $\mathbf{C u}$ & Cd & $\mathbf{Z n}$ & $\mathbf{P b}$ & pH \\
\hline \multirow[t]{2}{*}{ Side } & Right & $7177 \pm 7657^{\mathrm{a}}$ & $254 \pm 635^{\mathrm{a}}$ & $8464 \pm 6120^{a}$ & $752 \pm 1153^{a}$ & $7,52 \pm 0,46^{2}$ \\
\hline & Left & $7493 \pm 7752^{\mathrm{a}}$ & $119 \pm 534^{\mathrm{a}}$ & $7182 \pm 5416^{\mathrm{a}}$ & $731 \pm 144^{\mathrm{a}}$ & $7,58 \pm 0,41^{2}$ \\
\hline \multirow[t]{6}{*}{ Distance } & A & $14459 \pm 8648^{\mathrm{a}}$ & $230 \pm 201^{\mathrm{a}}$ & $11470 \pm 6650^{\mathrm{a}}$ & $1769 \pm 1576^{\mathrm{a}}$ & $7,7 \pm 0,61^{\mathrm{a}}$ \\
\hline & B & $12019 \pm 7248^{\mathrm{ab}}$ & $478 \pm 1035^{\mathrm{a}}$ & $9864 \pm 4708^{\mathrm{ab}}$ & $1310 \pm 1415^{\mathrm{ab}}$ & $7,6 \pm 0,30^{\mathrm{a}}$ \\
\hline & $\mathrm{C}$ & $7224 \pm 7792^{\mathrm{bc}}$ & $192 \pm 265^{\mathrm{a}}$ & $9501 \pm 6126^{\mathrm{ab}}$ & $659 \pm 968^{\text {ab }}$ & $7,8 \pm 0,12^{\mathrm{a}}$ \\
\hline & $\mathrm{D}$ & $4897 \pm 4621^{\mathrm{bc}}$ & $105 \pm 192^{\mathrm{a}}$ & $7088 \pm 5421^{\mathrm{ab}}$ & $413 \pm 629^{b}$ & $7,6 \pm 0,37^{\mathrm{a}}$ \\
\hline & $E$ & $2271 \pm 2039^{c}$ & $54,5 \pm 72,5^{\mathrm{a}}$ & $5018 \pm 3960^{b}$ & $181 \pm 256^{b}$ & $7,4 \pm 0,49^{\mathrm{a}}$ \\
\hline & $\mathrm{F}$ & $2707 \pm 4943^{c}$ & $59,9 \pm 135^{\mathrm{a}}$ & $3997 \pm 3939^{b}$ & $285 \pm 769^{b}$ & $7,3 \pm 0,41^{\mathrm{a}}$ \\
\hline \multirow[t]{6}{*}{ Sites } & 1 & $5446 \pm 5545^{\mathrm{ab}}$ & $332 \pm 1073^{\mathrm{a}}$ & $6679 \pm 5847^{\mathrm{abc}}$ & $269 \pm 276^{b}$ & $7,6 \pm 0,31^{\mathrm{a}}$ \\
\hline & 2 & $6073 \pm 5596^{\mathrm{ab}}$ & $80,7 \pm 138^{\mathrm{a}}$ & $10883 \pm 6306^{\mathrm{a}}$ & $531 \pm 937^{\mathrm{ab}}$ & $7,5 \pm 0,63^{\mathrm{a}}$ \\
\hline & 3 & $4771 \pm 5455^{b}$ & $78,6 \pm 112^{a}$ & $10698 \pm 6454^{\mathrm{ab}}$ & $252 \pm 353^{b}$ & $7,6 \pm 0,42^{\mathrm{a}}$ \\
\hline & 4 & $13675 \pm 10308^{a}$ & $226 \pm 175^{\mathrm{a}}$ & $10003 \pm 5905^{\mathrm{abc}}$ & $1616 \pm 1440^{\mathrm{a}}$ & $7,7 \pm 0,34^{\mathrm{a}}$ \\
\hline & 5 & $7974 \pm 9071^{\mathrm{ab}}$ & $200 \pm 223^{a}$ & $4688 \pm 2455^{\mathrm{bc}}$ & $1059 \pm 1690^{\mathrm{ab}}$ & $7,4 \pm 0,31^{\mathrm{a}}$ \\
\hline & 6 & $6113 \pm 6390^{\mathrm{ab}}$ & $202 \pm 259^{\mathrm{a}}$ & $3988 \pm 1630^{\mathrm{c}}$ & $888 \pm 1069^{\mathrm{ab}}$ & $7,4 \pm 0,47^{\mathrm{a}}$ \\
\hline
\end{tabular}

Where $\mathrm{A}=0.5 \mathrm{~m}, \mathrm{~B}=2.5 \mathrm{~m}, \mathrm{C}=5 \mathrm{~m}, \mathrm{D}=10 \mathrm{~m}, \mathrm{E}=20 \mathrm{~m}$, and $\mathrm{F}=50 \mathrm{~m}$ represent the distance from the taxiway. The exponents $\mathrm{a}, \mathrm{b}, \mathrm{c}$... correspond to the significant difference levels of the mean values and where also 1, 2, 3, 4, 5, and 6 represent the site before Somika and after Somika, Kilimasimba, Mimbulu farm, Kafubu river, and welcome panel at Kipushi.

It was observed that all means of MTE concentrations, as well as $\mathrm{pH}$ values, showed no significant differences depending on whether one is on the right or left side of the road. However, it was found that $\mathrm{Cu}, \mathrm{Zn}, \mathrm{and} \mathrm{Pb}$ concentrations decrease when moving away from the road. $\mathrm{Cu}$ showed three levels of concentrations significantly different from the five distances considered. The highest value corresponded to the distance of $0.5 \mathrm{~m}$, and the lowest equated to the distance of $20 \mathrm{~m}$ and $50 \mathrm{~m}$ from the road. The $\mathrm{Zn}$ significantly indicated two different levels. The point located at $0.5 \mathrm{~m}$ is significantly greater than points located at 20 and $50 \mathrm{~m}$ of the track. Lead also attested two major different levels with its highest value always located at $0.5 \mathrm{~m}$, but its lowest value was found at points $10 \mathrm{~m}$, $20 \mathrm{~m}$, and $50 \mathrm{~m}$ of the track.

Taking into account different sampling sites, $\mathrm{Cu}$ presented two levels where the highest value at site 4 (Mimbulu farm) and lowest at site 3 (Kilimasimba). Zinc also had two levels at site 2 (after Somika) and site 6 (Welcome panel of Kipushi) corresponding to the highest and lowest values. This was also the case for Pb_which showed two different sites.Its highest concentration corresponded to site 4, and its lowest concentrations were found at sites 1 (before Somika) and 3 (Kilimasimba). 


\section{Distribution of MTE Concentrations in Deep Soils (2 and $10 \mathrm{~cm})$ Around the Lubumbashi-Kipushi Road} Axis:

The one way ANOVA applied to the MTE concentrations defined their distribution by side, distance to track, and sampling site. The results of this analysis presented in Table 2.

The comparison of MTE and $\mathrm{pH}$ means on both sides of the road showed that there is no significant difference found between the right and left sides as it was the case for surface soils.

The evaluated path in terms of distance showed major differences for all MTEs. MTE concentrations decreased with distance to the track. The following table 3 summarizes the mean values of MTE and $\mathrm{pH}$ in soil depths.

Table 2:- Average Concentrations ( $\mathrm{mg} / \mathrm{kg}$ ) ofMetalTraceElements and $\mathrm{pH}$ inDeepSoils (2 to $10 \mathrm{~cm})$.

\begin{tabular}{|c|c|c|c|c|c|c|}
\hline Factors & & $\mathbf{C u}$ & Cd & Zn & $\mathbf{P b}$ & pH \\
\hline \multirow[t]{2}{*}{ Side } & Right & $7176 \pm 8148^{a}$ & $127 \pm 186^{\mathrm{a}}$ & $8330 \pm 5997^{\mathrm{a}}$ & $661 \pm 1170^{\mathrm{a}}$ & $7,4 \pm 0,47^{\mathrm{a}}$ \\
\hline & Left & $6287 \pm 7184^{\mathrm{a}}$ & $123 \pm 192^{\mathrm{a}}$ & $7145 \pm 5885^{\mathrm{a}}$ & $662 \pm 1123^{a}$ & $7,5 \pm 0,55^{\mathrm{a}}$ \\
\hline \multirow[t]{6}{*}{ Distance } & A & $14751 \pm 7173^{\mathrm{a}}$ & $263 \pm 239^{a}$ & $12201 \pm 5549^{\mathrm{a}}$ & $1806 \pm 1887^{\mathrm{a}}$ & $7,5 \pm 0,32^{\mathrm{a}}$ \\
\hline & $\mathrm{B}$ & $13590 \pm 9556^{\mathrm{a}}$ & $269 \pm 286^{\mathrm{a}}$ & $11023 \pm 6228^{\mathrm{a}}$ & $1292 \pm 1255^{\mathrm{ab}}$ & $7,6 \pm 0,34_{a}$ \\
\hline & $\mathrm{C}$ & $4592 \pm 4382^{b}$ & $74,2 \pm 89,3^{\mathrm{ab}}$ & $7793 \pm 6114^{\mathrm{ab}}$ & $353 \pm 393^{b c}$ & $7,6 \pm 0,77^{\mathrm{a}}$ \\
\hline & $\mathrm{D}$ & $3488 \pm 3978^{b}$ & $75,4 \pm 103^{\mathrm{ab}}$ & $6791 \pm 5433^{\mathrm{ab}}$ & $311 \pm 493^{b c}$ & $7,4 \pm 0,22^{a}$ \\
\hline & $\mathrm{E}$ & $1818 \pm 1832^{b}$ & $37,2 \pm 47,3^{b}$ & $4575 \pm 4001^{b}$ & $133 \pm 188^{\mathrm{c}}$ & $7,3 \pm 0,59^{\mathrm{a}}$ \\
\hline & $\mathrm{F}$ & $2151 \pm 2901^{b}$ & $32,2 \pm 18,6^{b}$ & $4044 \pm 3764^{b}$ & $73,2 \pm 129^{c}$ & $7,3 \pm 0,60^{\mathrm{a}}$ \\
\hline \multirow[t]{6}{*}{ Sites } & 1 & $4957 \pm 4941^{\mathrm{a}}$ & $18,8 \pm 23,7^{b}$ & $6512 \pm 5636^{\mathrm{abc}}$ & $178 \pm 168^{b}$ & $7,5 \pm 0,19^{\mathrm{a}}$ \\
\hline & 2 & $4896 \pm 5515^{a}$ & $43,6 \pm 62,6^{\mathrm{ab}}$ & $8438 \pm 5976^{\mathrm{abc}}$ & $221 \pm 368^{b}$ & $7,3 \pm 0,58^{\mathrm{a}}$ \\
\hline & 3 & $5484 \pm 5665^{\mathrm{a}}$ & $91,2 \pm 117^{\mathrm{ab}}$ & $12180 \pm 8357^{\mathrm{a}}$ & $334 \pm 498^{\mathrm{ab}}$ & $7,3 \pm 0,36^{\mathrm{a}}$ \\
\hline & 4 & $11794 \pm 12132^{a}$ & $231 \pm 223^{\mathrm{a}}$ & $10641 \pm 6291^{\mathrm{ab}}$ & $1521 \pm 1838^{a}$ & $7,7 \pm 0,49^{\mathrm{a}}$ \\
\hline & 5 & $7295 \pm 8163^{\mathrm{a}}$ & $179 \pm 228^{\mathrm{ab}}$ & $4447 \pm 1770^{\text {bc }}$ & $811 \pm 1155^{\mathrm{ab}}$ & $7,6 \pm 0,80^{\mathrm{a}}$ \\
\hline & 6 & $5964 \pm 6185^{\mathrm{a}}$ & $187 \pm 258^{\mathrm{ab}}$ & $4201 \pm 2044^{\mathrm{c}}$ & $902 \pm 1328^{\mathrm{ab}}$ & $7,3 \pm 0,32^{\mathrm{a}}$ \\
\hline
\end{tabular}

Where $\mathrm{A}=0.5 \mathrm{~m}, \mathrm{~B}=2.5 \mathrm{~m}, \mathrm{C}=5 \mathrm{~m}, \mathrm{D}=10 \mathrm{~m}, \mathrm{E}=20 \mathrm{~m}$, and $\mathrm{F}=50 \mathrm{~m}$ represent the distance from the taxiway. The exponents $\mathrm{a}, \mathrm{b}, \mathrm{c}$... correspond to the significant difference levels of the mean values were 1, 2, 3, 4, 5, and 6 also represent the site before Somika, andafter Somika, Kilimasimba, Mimbulu farm, Kafubu river, and Welcome panel at Kipushi.

$\mathrm{Cu}$ decreases in distances $\mathrm{A}(0.5 \mathrm{~m})$ and $\mathrm{B}(2.5 \mathrm{~m})$ at distances $\mathrm{C}(5 \mathrm{~m}), \mathrm{D}(10 \mathrm{~m}), \mathrm{E}(20 \mathrm{~m})$ and F (50m). While the concentration of $\mathrm{Cd}$ and $\mathrm{Zn}$ decreases with the distance from $\mathrm{A}$ and $\mathrm{B}$ to the distance $\mathrm{E}$ and $\mathrm{F}$. However, $\mathrm{Pb}$ showed its decay in three distances from distance A to distances $\mathrm{C}$, and $\mathrm{D}$ and the distance $\mathrm{E}$, and $\mathrm{F}$.

Distribution of ETM Concentrations in the Two Soil Depths (Surface- Depth) Around the LubumbashiKipushi Road Axis:

In this part of the work, the mean values of the concentrations of the MTE and $\mathrm{pH}$ of the soil of the first depth (0 to $2 \mathrm{~cm})$ and those of the second depth $(2$ to $10 \mathrm{~cm})$ are compared. The results of this analysis are presented in Table 3.

Table 3:- AverageConcentrations (mg/kg) of MTE and $\mathrm{pH}$ inBothDepths (0 to 2 and 2 to $10 \mathrm{~cm})$ for allDistances andSites.

\begin{tabular}{|l|l|l|l|l|l|l|}
\hline MTE & & Cu & Cd & Zn & Pb & pH \\
\hline \multirow{2}{*}{ Level } & Surface & $7332 \pm 7640^{\mathrm{a}}$ & $152 \pm 216^{\mathrm{a}}$ & $7823 \pm 5728^{\mathrm{a}}$ & $769 \pm 1159^{\mathrm{a}}$ & $7,6 \pm 0,43^{\mathrm{a}}$ \\
\cline { 2 - 7 } & Depth & $6732 \pm 7640^{\mathrm{a}}$ & $125 \pm 187^{\mathrm{a}}$ & $7738 \pm 5930^{\mathrm{a}}$ & $661 \pm 1138^{\mathrm{a}}$ & $7,5 \pm 0,51^{\mathrm{a}}$ \\
\hline
\end{tabular}

The exponents $a, b, c$... correspond to the significant difference levels of the mean values.

The result of this table shows that no significant difference between the concentrations of the MTE and $\mathrm{pH}$ of these two depths was found on all the MTEs and $\mathrm{pH}$. This provides strong evidence to consider that the two depths sampled as identical.

\section{Relationship Between Variables:}

The relationships between variables in the soil surface are illustrated in Figure 3. The principal component analysis (PCA) carried out on the data shows that the first two axes account for more than $80 \%$ of the variance and can be considered representative of the behavior of variables studied in these two depths. 


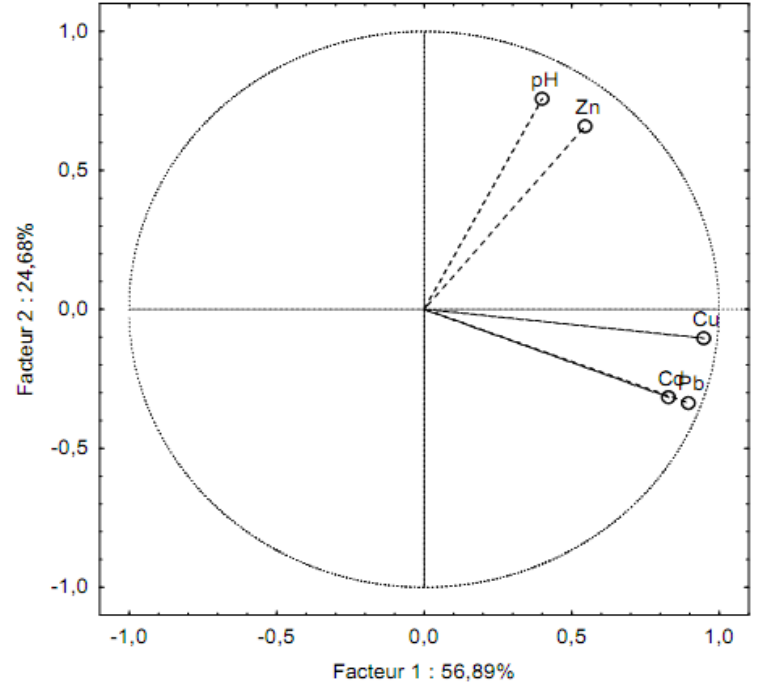

a. Depth 0 to $2 \mathrm{~cm}$

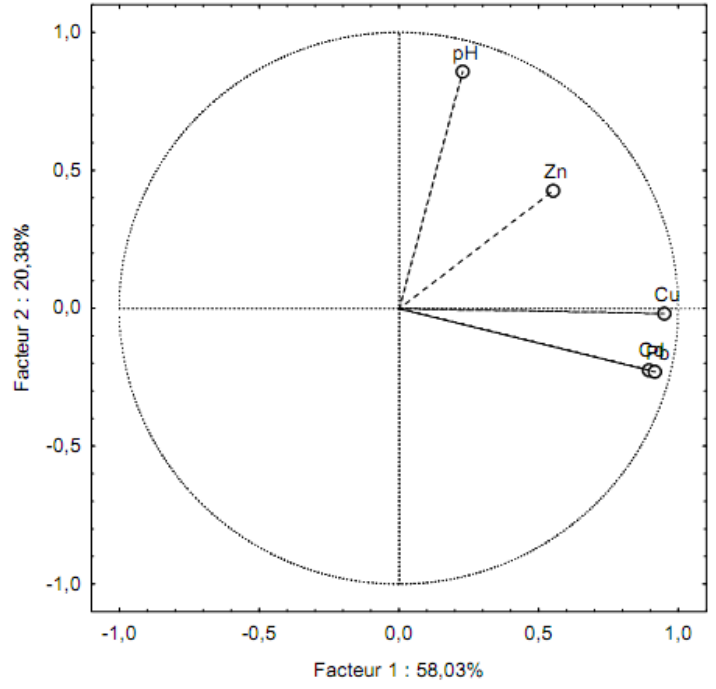

b. Depth 2 to $10 \mathrm{~cm}$

Figure 3:- Principal Component Analysis (PCA) of Soil Depth Variables.

Copper, $\mathrm{Pb}$ and $\mathrm{Cd}$ are proportionally associated and have no relationship to $\mathrm{Zn}$ and $\mathrm{pH}$. This is equivalent to say that the first three elements could come from the same source while the speciation of $\mathrm{Zn}$ could be more influenced by $\mathrm{pH}$.

At depth (Figure 3a), CPA is representative to surface soils as well as in deep soils (Figure 3b). However, the behavior of $\mathrm{Zn}$ is slightly modified in the second depth. $\mathrm{Zn}$ exhibits intermediate behavior between $\mathrm{Cu}, \mathrm{Cd}, \mathrm{Pb}$ group, and $\mathrm{pH}$. Nevertheless, $\mathrm{pH}$ remains indifferent to $\mathrm{Cu}, \mathrm{Cd}$, and $\mathrm{Pb}$ in this second depth.

It is observed that the relationships between all the samples studied remain close to those of two depths carried out separately. The first two axes once again represent a variant close to $80 \%$.

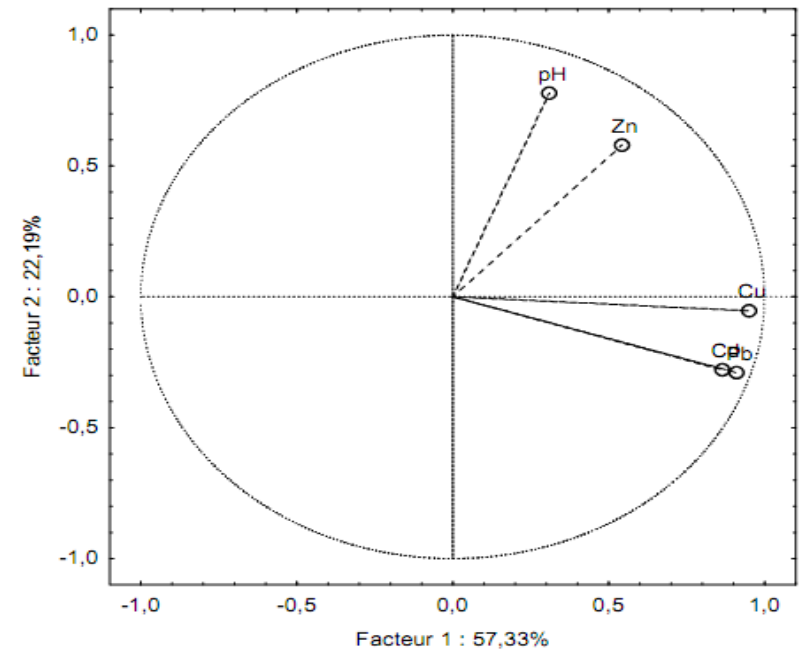

Figure 4:- Principal Components Analysis (PCA) of Soil Variables from Two Depths (0 to 2 and 2 to $10 \mathrm{~cm}$ ).

The $\mathrm{pH}$ remains indifferent with respect to $\mathrm{Cu}, \mathrm{Cd}$, and $\mathrm{Pb}$, but it is rather close to $\mathrm{Zn}$. This shows that the behavior of $\mathrm{Zn}$ is more governed by $\mathrm{pH}$ changes than it will be with the other three elements. The change in $\mathrm{pH}$ would affect $\mathrm{Zn}$ much more than $\mathrm{Cu}, \mathrm{Cd}$, and $\mathrm{Pb}$. 


\section{Discussion:-}

The vehicle traffic on the Lubumbashi-Kipushi road affected the soil MTE concentrations on both sides of the road at the same level. This implies that the dispersion of the MTE has been fair and equitable on both sides of the road. Wind direction and other factors, such as runoff acting on the movement of the elements on the soil surface would have not affect the distribution of MTE.

The significant effect of distance on the distribution of trace elements on both sides of the Kipushi Road can be explained by anthropogenic contamination. Concentrations of MTE decreased with distance to the road. The noneffect of distance on $\mathrm{Cd}$ in this soil layer would have resulted from its higher mobility compared to the other three MTEs (Isabelle, 1999). Thus, Cd would have migrated a little deeper than the other three elements and kept its surface concentration close to the natural soil.

The variation in concentrations relative to the sites might have derived from accidental or soil type at the sites that significantly showed different MTE values. According to Mmolawa et al (2011), the sources of contamination along the road were due to human activities, vehicle emissions, and site lithology. Sites 4 and 3 have a similarity in Cu and $\mathrm{Pb}$ concentration because these two MTE similarly evolve in both sites. This is explained by the fact that these two elements gradually migrated in-depth because they proceed from an origin of external contamination. Road traffic can be considered as the cause of this contamination as found by Pagotto (1999).

The side factor remains without a significant impact on the distribution of the metallic traced elements studied, as it was the case on the surface soil. However, Pagotto (1999) discovered a contrary finding following the prevailing wind that blows perpendicularly to the track. The axis (Lubumbashi-Kipushi) studied is found to be parallel to the dominant wind (Pagotto, 1999).

Once again, the distance from the road affects the distribution of all MTE. This result could mean that the contamination impact was spread beyond the two depths. The toxic effects of $\mathrm{Cu}$ would be more expressed on the surface than at the depth. This could be related to the weakness of the second depth considered in this study.

The sites show a variation concerning all elements except for $\mathrm{Cu}$. This means that the high concentration of $\mathrm{Cu}$ observed at point 4 would be accidental. Otherwise, the variation could also occur in this soil layer. Lead, on the other hand, maintains its high concentration on site 4 . This behavior can be explained by the fact that $\mathrm{Cu}$ and $\mathrm{Pb}$ are considered to be less mobile than $\mathrm{Zn}$ and $\mathrm{Cd}$ (Isabelle, 1999). However, the intrinsic behavior of these two elements could explain the change in $\mathrm{Cu}$ behavior in this layer. The nature of the element under consideration also influences its behavior in a given environment (Delmas, 2000).

It should be noted that the factors considered in this study had no effect on soil acidity. The nature of the substrate causes thecontamination that does not contain acid-generating elements or compounds. In soils, some elements, such as calcium and magnesium or both together, or any compound containing them (limestone, lime, dolomites, etc.) decrease the acidity when they are in high concentration (Hlavackova, 2005).

The lack of significant difference in MTE concentrations in the two depths considered would be justified by the fact that the depths studied are very close (weak). From an agronomic point of view, $2 \mathrm{~cm}$ is insignificant, and the depths to be observed should be somewhat greater than those considered in this study.

The distribution of variables into two groups expresses two distinct behaviors that exist between them. The almost orthogonal positioning of the groups proves that there is almost no relationship between the $\mathrm{pH}-\mathrm{Zn}$ group and $\mathrm{Cu}-$ $\mathrm{Pb}-\mathrm{Cd}$. Otherwise, the approximation between the variables in each group expresses their close behavioral relationship. Therefore, they are associated with one another. The association of a group with the major axis of the PCA gives two variables of the main factors of the system. Thus, $\mathrm{Cu}, \mathrm{Pb}$, and $\mathrm{Cd}$ are major factors of the variables and exhibit similar behavior in their distribution. The non-association of $\mathrm{Zn}$ with the other three MTE would mean that this element could have a natural origin and non-anthropogenic. This is supported by its behavior in the second depth where the $\mathrm{Zn}$ is slightly detached from $\mathrm{pH}$ and approaches three other MTE (Figure $3 \mathrm{~b}$ ).

Although $\mathrm{Zn}$ has approached $\mathrm{Cu}, \mathrm{Cd}$, and $\mathrm{Pb}$, it is generally governed by the $\mathrm{pH}$ (Figure $3 \mathrm{a}$ ). The absence of a clear relationship between $\mathrm{Cu}, \mathrm{Cd}$, and $\mathrm{Pb}$ with $\mathrm{pH}$ can be clarified by the fact that they have higher concentrations than in 
a natural situation, and their forms would not be favorable to the action of $\mathrm{pH}$. This significantly reduces the impact of $\mathrm{pH}$ on these three elements.

\section{Conclusion:-}

The study assessed the contamination of soils along the roads by MTEs from anthropogenic activities due to road traffic. To achieve this, the Lubumbashi-Kipushi axis was the target of this research in the road sector followed by the transport of minerals since the colonial times. Six sampling sites and two sides per site were investigated. In order to determine the influence of the road on soil contamination, six points at different distances from each other, on each side, away from the road were taken, namely $(0.5 \mathrm{~m}, 2.5 \mathrm{~m}, 5 \mathrm{~m}, 10 \mathrm{~m}, 20 \mathrm{~m}$, and $50 \mathrm{~m})$.

The analysis of the main components shows that there is a correlation of the variables whose percentage of two axes at the surface and at depth is $80 \%$. The two depths demonstrate that the $\mathrm{pH}$ remains indifferent with respect to $\mathrm{Cu}$, $\mathrm{Cd}$, and $\mathrm{Pb}$, but it is rather close to $\mathrm{Zn}$. This indicates that the behavior of $\mathrm{Zn}$ is more controlled by $\mathrm{pH}$ variations than it is with the other three elements. The change in $\mathrm{pH}$ would affect $\mathrm{Zn}$ much more than $\mathrm{Cu}, \mathrm{Cd}$, and $\mathrm{Pb}$.

Given the high concentrations at the site studied, it appears that the contamination emitted in the road environment can have an impact on crops. Since the spread of contaminants is often possible; thus, crops could begin at a distance of $50 \mathrm{~m}$ to avoid contamination due to the road traffic, which can be negligible at this particular distance.

\section{Conflicts of Interest:}

The authors of this paper did not encounter financial problems to contribute toward the realization and publication of this research.

\section{Author Contributions:}

Conceptualization, Data curation, Formal analysis, Funding acquisition, Investigation, Methodology, Software and Writing - original draft: Muhune KituleSimon, Supervision: Kalonda Mutombo Emery and Mbayo Kitambala Marsi, Writing - review \& editing: Muhune Kitule Simon, Mbayo Kitambala Marsi, Tshisand Tshibwid Patrick, Muyumba Nonga Welcome, Kaya Muyumba Donato,Banza Ilunga Bienvenue,Misenga Twite Antoinette,Lukusa Tresor,Tshibanda Kabumana Dieudonne,Kalonda MutomboEmery, and Lumbu Simbi Jean-Baptiste.

\section{References:-}

1. Adriano, D. C. (2001). Trace Elements in the Terrestrial Environment. Springer Verlag. New York, p 866

2. Akujobi, C. O., Odu, N. N., \& Okorondu, S. I. (2012). Bioaccumulation of Lead by Bacillus Species Isolated from Pig Waste. Journal of Research in Biology, 2: 83-9

3. Augusto Costa, A. C., \& Pereira Duta, F. (2001). Bioaccumulation of Copper, Zinc, Cadmium, and Lead by Bacillus sp., Bacillus cereus, Bacillus speaerecus and Bacillus subtillus. Brazilian Journal of Microbiology: pp: $32-50$

4. Baize, D. (1997). Teneurs totales en éléments traces métalliques dans les sols (France); Edition INRA; pp 258260.

5. Carrillo-González, R., Šimůnek, J., Sauve, S., \& Adriano, D. (2006). Mechanisms and Pathways of Trace Element Mobility in Soils. Advances in Agronomy, 91, 111-178

6. Delmas, G. C. (2000). Influence des Conditions Physico- Chimiques sur la Mobilité du Plomb et du Zinc dans le Sol et un Sédiment en Domaine Routier; Thèse de doctorat; Université de Pau et des Pays de l'Adour, pp 21$39,68-78,157-160$

7. Hlavackova, P. (2005). Evaluation du Comportement du Cuivre et du Zinc dans une Matrice de Type Sol à l'Aide de Différentes Méthodologies; Science et Techniques du Déchet; Institut National des Sciences Appliquées de Lyon; pp 57-70

8. Ghrefat, H., \& Yusuf, N. (2006). Assessing Mn, Fe, Cu, Zn, and Cd Pollution in Bottom Sediments of Wadi AlArab Dam, Jordan. Chemosphere, 65(11), 2114-2121

9. Isabelle, M. (1999). Infiltration des Eaux de Ruissellement Pluvial et Transfert de Polluants Associés dans le Sol, Urbain - vers une Approche Globale et Pluridisciplinaire. Diplôme d'ÉtudesApprofondies, p 38

10. Kitobo W (2009); Dépollution et Valorisation des Rejets Miniers Sulfurés du Katanga « cas des tailings de l'ancien concentrateur de Kipushi. Thèse à l'Université de Liège; Facultés des Sciences Appliquées, pp 1-9

11. Lee, C. G., Chon, H. T. \& Jung, M. C. (2001). Heavy Metal Contamination in the Vicinity of the Daduk Au$\mathrm{Ag}-\mathrm{Pb}-\mathrm{Zn}$ mine in Korea. Applied Geochemistry, 16: 1377-86 
12. Mmolawa, K. B., Likuku, A. S., \& Gaboutloeloe, G. K. (2011). Assessment of Heavy Metal Pollution in Soils Along Major Roadside Areas in Botswana. African Journal of Environmental Science and Technology, 5(3), 186-196

13. Muyumba, D. K., Liénard, A., Mahy, G., Luhembwe, M. N., \& Colinet, G. (2015). Caractérisation des Systèmes Sols-plantes dans les Collines de l'arc Cuprifère du Katanga (synthèse bibliographique). Biotechnologie, Agronomie, Société et Environnement, 19(2), 204-214

14. Muyumba, N. W., Kalonda, M. E., Mbayo, K. M., Kapasi, K. V., Ilunga, B. B., Chipeng, K. F., Lukumu, M. E., Tshibanda, K. D., Ngoy, K. E., Muleka, K. C. \& Lumbu, S.J-B. (2020). Impact du Transport Routier sur le Dépôt et le Transfert du Plomb et du Zinc dans le Sol sur la Route Lubumbashi-Likasi (RD Congo), International Journal of Innovation and Applied Studies, (Sous- Presse)

15. Muyumba, N. W., Kapasi, K. V., Kalonda M. E., Mbayo K. M., Tshisand T. P., Chipeng K. F., Ngoy K. E., and Lumbu, S. J-B, (2016), "Contribution ofTraceMetals inWater from theUndergroundMining of Kipushi in Kafubu river (DR Congo)," International Journal of Innovation and Applied Studies, vol. 15, no. 4, pp. 864-871

16. Nhari, F., Sbaa, M., Vasel, L., Fekhaoui, M., \& El Morhit, M. (2014). La Contamination des Sols d'une Décharge non Contrôlée par les Métaux Lourds:Cas de la Décharge Ahfir- Saidia (Maroc Oriental); p: 1477

17. Pagotto, C. (1999). Etude sur l'Émission et le Transfert dans les Eaux et les Sols des Éléments Traces Métalliques et des Hydrocarbures en Domaine Routier. Thèse de Doctorat; Université de Poitiers, pp: 220-234

18. Setra, (2004). La Pollution des Sols et des Végétaux à Proximité des Routes, pp 2-3,11

19. Ward, N. I., Brookes, R. R., Roberts, E. \& Boswell, C. R. (1977). Heavy Metal Pollution from Automotive Emission and Its Effect on Roadside Soils and Pasture Species in New Zealand. Environmental Science and Technology, 917-920. 